typical of spermatozoa as seen in Fig. 2. The bacteria, on the contrary, grow in more than one direction, a feature well brought out in Buchner's illustrations mentioned above. On account of the large size of the bacteria found in $T$. assamensis, it has made possible the correct interpretation of more than one mysterious problem in the literature on symbiosis.

Sulc's illustration (Fig. 2) is a genuine representa. tion of an insect testis, only misinterpreted as a tumour; but his Fig. 1 here has been idealized as a bacterium to suit a preconceived theory. The wavy shape of the objects in Fig. 2 further suggests their being spermatozoa.

Biochemical Laboratory,

Osmanaia Medical College,

Hyderabad, Deccan. Nov. 25.

1 "Tiere u. Pflanze in intrazellular Symbiose" (1930).

${ }^{2}$ Publ. Biolog. de l'école des hautes études vétérin., 3, 2 (Brno, 1924). ${ }^{8} Z$. morph. u. Ökol., 4 (1925).

- Verh. VII Intern. Kongr. Entom., 2, 877 (Berlin).

\section{Helminth Parasites of Limpets}

DURING investigations of the helminth parasites of the British limpets Patella vulgata, $P$. intermedia and $P$. depressa ${ }^{1,2}$ in relation to a possible bearing of parasitism on mortality and sex-proportions ${ }^{3}$, three larval trematodes (Cercaria patello Lebour ${ }^{4}$, an unidentified Xiphidiocercaria and an unidentified tailless cercaria) and one larval cestode have been found (see table).

\begin{tabular}{|c|c|c|c|c|c|}
\hline \multirow{2}{*}{$\begin{array}{c}\text { Host } \\
\text { species }\end{array}$} & \multirow{2}{*}{$\begin{array}{l}\text { No. of } \\
\text { speci- } \\
\text { mens } \\
\text { exam- } \\
\text { ined }\end{array}$} & \multicolumn{4}{|c|}{ Number of specimens found infested with } \\
\hline & & C. patellbe & $\underset{\text { cercaria }}{\text { Xiphidio- }}$ & $\begin{array}{l}\text { Tailless } \\
\text { cercaria* }\end{array}$ & Cestode \\
\hline & 3631 & $121(3 \%)$ & $7(0 \cdot 2 \%)$ & $22(4 \%)$ & $4(0 \cdot 1 \%)$ \\
\hline $\begin{array}{l}\text { media } \\
\text { P. depressa }\end{array}$ & $\begin{array}{r}595 \\
1417\end{array}$ & $\begin{array}{r}49(8 \%) \\
278(20 \%)\end{array}$ & $\underset{\text { nil }}{10(i \cdot 7 \%)}$ & $\begin{array}{l}26(19 \%) \\
12(5 \%)\end{array}$ & $1 \underset{\text { nil }}{1(0 \cdot 2 \%)}$ \\
\hline
\end{tabular}

* Only 957 specimens (all species) were examined for this parasite.

C. patelloe is the commonest, is most abundant in autumn and is of special interest as a source of living cercariæ for class-work. It has been found on the west coast of Britain in several localities between Cornwall and Millport, and at Aberdeen, Cullercoats and Plymouth, being most abundant in $P$. depressa at Port St. Mary, Isle of Man, and at Trevone, north Cornwall.

Each of the three trematodes occurs independently in the digestive gland, the cestode being encysted on the surface of the visceral mass. The tailless cercaria is visible only under the microscope in smears of digestive gland tissue, but infestations of each of the other three parasites can usually be seen on lifting the foot forward from the visceral mass.

$C$. patellae is commonest in $P$. depressa, but since in all three species it is more common in populations inhabiting rock pools than in those living in exposed situations, the apparent preference for $P$. depressa may be because this species occurs in pools or at low water, whereas the other species frequent 'dry' habitats.

Most limpets infested with $C$. patelloe are in the larger size (age) groups. The infestation in $P$. depressa at Port St. Mary is 10 per cent in specimens less than $35 \mathrm{~mm}$. in length, increasing to 100 per cent in those

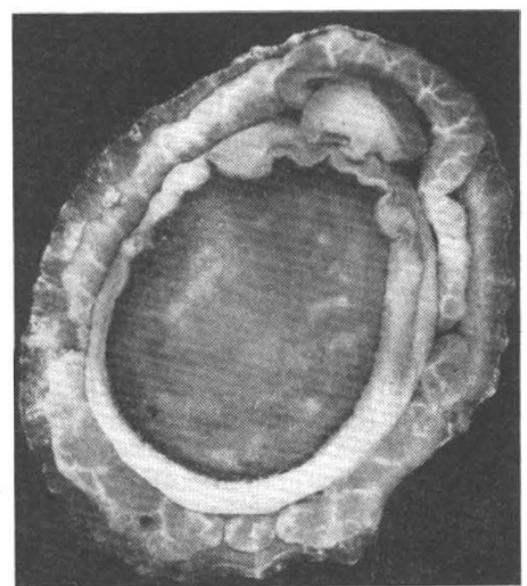

Patella depressa (TREVONE) SHOWING MANTLE VEINLETS FILLED WITH CERCARIAR READY FOR ESCAPE. (NATURAL SIZE)

more than $65 \mathrm{~mm}$. (cf. Rothschild $\left.{ }^{5,6}\right)$. One of the more obvious effects of parasitism is castration of the host, infested limpets rarely having gonads normal in size; only 20 per cent, about two thirds of which were female, were found with identifiable sex products. The effects of infestation on the host organs have been discussed by Rees?. There is no apparent difference in vitality between infested and uninfested limpets, although in the final stages of infestation only a very small portion of the digestive gland remains unaffected. Infestation may, however, have an important effect on mortality and sex ratio in the larger individuals of all three species.

The sporocysts of the Xiphidiocercaria are restricted to a limited portion of the digestive gland or, rarely, kidney. No sporocysts of the tailless cercaria have been observed.

$C$. patella has been found to escape from the host by means of the veinlets in the mantle skirt which, filled with cercariæ, show white and opaque against the translucent mantle (Fig. 1). It is suggested that migration of cercariæ within the hæmocœle, and subsequent escape from the mantle, may be a common occurrence in other molluses infested with larval trematodes.

The number of cercariæ given off by the limpet in vitro is greatest just after immersion in water. Up to 330 cercariæ may emerge in the first hour, the rate of escape then steadily falling and finally ceasing after about thirty hours immersion (compare Cort ${ }^{8}$ ). Under natural conditions there is probably a rhythm imposed by tidal fluctuations, the ceroariæ only escaping when the host is covered by the tide.

The final host of $C$. patelloe is as yet unknown, although $\mathrm{Nicoll}^{4}$ suggested that it may be a bird. It is possible that moribund or recently dead seabirds, perhaps fouled with oil, may provide material, for which I should be grateful.

A full account of the work will be published later.

Department of Zoology, W. Crewe

University of Liverpool.

$$
\text { Dec. } 17 .
$$

${ }^{1}$ Fischer-Piette, E., J. Conchyliol., 79, 5 (1935).

'Eslick, A., Proc. Linn. Soc. Lond., Session 152, 45 (1940).

${ }^{3}$ Orton, J. H., Nature, 158, 173 (1946).

- Lebour, M. V., Parasit., 4, 416 (1911).

s Rothschild, M., J. Mar. Biol. A880c. U.K., 20 (3), 537 (1936).

- Rothschild, M., J. Mar. Biol. Assoc. U.K., 25 (1), 69 (1941).

7 Rees, F. G., Proc. Zool. Soc. Lond., 45 (1934).

${ }^{8}$ Cort, W. W., J. Parasit., 8, 177 (1922). 